\title{
ASIMILASI BAGI NARAPIDANA DALAM RANGKA PELAKSANAAN INTEGRASI UNTUK PENCEGAHAN DAN PENANGGULANGAN PENYEBARAN COVID-19 (Studi Kasus Pada Balai Pemasyarakatan Kelas I Padang)
}

\author{
1) Yessy Irawan, ${ }^{2)}$ Fahmiron, ${ }^{3)}$ Iyah Faniyah \\ ${ }^{1)}$ Program Magister Ilmu Hukum,Universitas Ekasakti, Padang, Indonesia \\ Email: yessyirawan21@gmail.com \\ ${ }^{2)}$ Universitas Ekasakti, Padang, Indonesia \\ Email: fahmiron@gmail.com \\ ${ }^{3)}$ Universitas Ekasakti, Padang, Indonesia \\ Email: iyahfaniyah01@gmail.com
}

\begin{abstract}
The Indonesian government has designated the outbreak of the deadly Covid-19 virus as a National Disaster, and designated Covid-19 as a public health emergency through Presidential Decree No. 11 of 2020. This has had a profound impact on the overcapacity condition of prisons, making them very vulnerable to transmission. Covid-19. In order to make efforts to rescue prisoners, it is necessary to release and release them through assimilation for the prevention and control of the spread of Covid-19 under the supervision of the Fathers, especially here at the Class I prisons in Padang through Permenkumham Number 32 of 2020.
\end{abstract}

Keywords: Covid-19, Over Capacity, Assimilation

\begin{abstract}
ABSTRAK
Pemerintah Indonesia menetapkan wabah penyebaran virus mematikan Covid-19 ini sebagai Bencana Nasional, dan menetapkan Covid-19 sebagai kedaruratan kesehatan masyarakat melalui Keputusan Presiden Nomor 11 Tahun 2020. Hal ini sangat berdampak juga dengan kondisi Lembaga Pemasyarakatan yang over kapasitas sehingga menjadi tempat sangat rentan penularan Covid-19. Untuk melakukan upaya penyelamatan terhadap narapidana perlu dilakukan pengeluaran dan pembebasan melalui asimilasi untuk pencegahan dan penanggulangan penyebaran Covid-19 dibawah pengawasan Bapas, khususnya disini Pada Bapas Klas I Padang melalui Permenkumham Nomor 32 Tahun 2020.
\end{abstract}

Kata Kunci: Covid-19, Over Kapasitas, Asimilasi

\section{PENDAHULUAN}

Pada tanggal 10 Februari 2020 Corona Virus Disease 2019 (Covid-19) dinyatakan oleh Organisasi Kesehatan Dunia (World Health Organization) sebagai pandemi karena virus ini sudah menyebar hampir ke seluruh negara di dunia. Pemerintah Indonesia menetapkan wabah penyebaran virus mematikan Covid-19 ini sebagai Bencana Nasional pada tanggal 14 Maret 2020 dan menetapkan Covid-19 sebagai kedaruratan kesehatan masyarakat melalui Keputusan 
Presiden Nomor 11 Tahun 2020. Penetapan tersebut didasarkan pada penyebaran Corona Virus Disease 2019 (Covid-19) yang bersifat luar biasa dengar ditandai jumlah kasus dan/atau jumlah kematian telah meningkat dan meluas lintas wilayah dan lintas negara dan berdampak pada aspek politik, ekonomi, sosial, budaya, pertahanan dan keamanan, serta kesejahteraan masyarakat di Indonesia. Hal ini sangat berdampak juga dengan kondisi Lembaga Pemasyarakatan yang over kapasitas.

Kepadatan narapidana menimbulkan lembaga pemasyarakatan menjadi tempat yang sangat rentan terjadinya penularan virus Covid-19 secara masif dan cepat, jika salah satu dari penghuni lapas terkena virus tersebut. Mengingat para petugas pemasyarakatan tidak tinggal di dalam lapas, melainkan di luar kompleks lapas yang sudah barang tentu berinteraksi dengan masyarakat sekitarnya. Ditambah lagi pemerintah telah mengeluarkan kebijakan untuk menerapkan physical distancing. ${ }^{1}$ Atas dasar itu maka sangat urgent untuk mengambil tindakan untuk mencegah dan menghalau penyebaran Covid-19 di dalam lembaga pemasyarakatan.

Pemerintah melalui Kementerian Hukum dan Ham dalam melakukan upaya pencegahan dan penyebaran Covid-19 di Lembaga Pemasyarakatan telah mengeluarkan "Peraturan Menteri Hukum dan HAM RI No.10 Tahun 2020 Tentang Syarat Pemberian Asimilasi dan Hak Integrasi Bagi Narapidana dan Anak dalam Rangka Pencegahan dan Penanggulangan Penyebaran Covid-19 dan Keputusan Menteri Hukum dan HAM RI No.19.PK.01.04 Tahun 2020 tentang Pengeluaran dan Pembebasan Narapidana Anak Melalui Asimilasi dan Integrasi dalam Rangka Pencegahan dan Penanggulangan Penyebaran Covid19”. Peraturan tersebut mendapatkan tanggapan pro maupun kontra di tengah-tengah masyarakat. Tetapi diluar daripada itu peraturan ini ditetapkan dalam rangka penanggulangan dan pencegahan penyebaran COVID-19 ditengah kondisi sejumlah penjara yang menampung tahanan dan narapidana melebihi kapasitas yang ada.

Pembebasan terhadap narapidana menimbang akan rawannya penyebaran Covid-19 di dalam lembaga pemasyarakatan dan rumah tahanan negara di Indonesia yang notabenenya mengalami kelebihan penghuni (over kapasitas). Dengan adanya pengeluaran narapidana dan anak yang ada di dalam lapas dan rutan seluruh Indonesia, diharapkan dapat mencegah dan menanggulangi penyebaran virus corona. Akan tetapi konsekuensi hukum lain justru bisa terjadi, manakala skenario pembebasan napi itu tidak berjalan baik. Narapidana yang mendadak bebas itu tak ada jaminan bahwa mereka tak mengulangi tindak kejahatan lagi. Hal inilah kemudian yang menjadi kekhawatiran masyarakat pasca narapidana itu bebas.

Narapidana dan anak ${ }^{2}$ yang diberikan asimilasi serta integrasi telah melalui tahap penilaian perilaku. Mereka dinilai sudah berkelakuan baik, mengikuti program pembinaan dan tidak melakukan tindakan pelanggaran disiplin dalam lembaga. Sebelum mereka kembali ke masyarakat petugas pemasyarakatan memberikan edukasi, menyampaikan aturan-aturan kedisiplinan yang tidak boleh dilanggar selama menjalankan asimilasi dan integrasi serta

${ }^{1}$ Safaruddin Harefa, Kebijakan Kriminal Dalam Menanggulangi Kelebihan Kapasitas Lembaga Pemasyarakatan, Jurnal Yuridis, Volume 5, No. 2, 2020, hlm. 294

${ }^{2}$ OKENEWS, Polemik Pembebasan Napi Ditengah Pandemi Covid-19, https://nasional.okezone.com/read/2020/04/12/337/2197945/polemik-pembebasan-napi-di-tengah-pandemicovid-19 [10/11/2020] 
sanksi yang akan mereka peroleh apabila melanggar, seperti membuat keresahan di masyarkat apalagi mengulangi melakukan tindak pidana.

Untuk melakukan upaya penyelamatan terhadap narapidana dan anak yang berada di Lembaga Pemasyarakatan, Lembaga Pembinaan Khusus Anak, dan Rumah Tahanan Negara, perlu dilakukan pengeluaran dan pembebasan melalui asimilasi dan integrasi untuk pencegahan dan penanggulangan penyebaran Covid-19 dibawah pengawasan Balai Pemasyarakatan, khususnya disini Pada Balai Pemasyarakatan Klas I Padang.

\section{METODE PENELITIAN}

Metode penelitian yang digunakan dalam penelitian tesis ini adalah sebagai berikut:

\section{Spesifikasi Penelitian}

Penelitian dalam rangka penyusunan tesis ini termasuk dalam penelitian deskriptif analitis, yaitu penelitian yang menggambarkan tentang asimilasi bagi narapidana dalam rangka pelaksanaan integrasi untuk pencegahan dan penanggulangan penyebaran Covid19 pada Balai Pemasyarakatan Klas I Padang.

\section{Metode Pendekatan}

Metode pendekatan yang digunakan dalam penelitian ini adalah pendekatan yuridis normatif yang didukung oleh pendekatan yuridis empiris. Penelitian dengan pendekatan yuridis normatif digunakan untuk menganalisis kaedah-kaedah hukum yang ada dalam data hukum yang berkaitan dengan pengaturan dan pelaksanaan kewenangan dari Balai Pemasyarakatan dalam pemberian asimilasi bagi narapidana dalam rangka pelaksanaan integrasi untuk pencegahan dan penanggulangan penyebaran Covid-19, dalam rangka menemukan asas-asas dan konsepsi serta dasar-dasar pemikiran yang berhubungan dengan penelitian ini. Sedangkan pendekatan yuridis empiris dilakukan untuk praktek-praktek pengaturan dan kewenangan dari Balai Pemasyarakatan sesuai dengan kaedah-kaedah hukum yang berlaku.

\section{PEMBAHASAN}

A. Pemberian Asimilasi Bagi Narapidana Dalam Rangka Pelaksanaan Integrasi Untuk Pencegahan Dan Penanggulangan Penyebaran Covid-19

Pandemi Covid-19 (Corona Virus Desease 2019) ini membuat warna Pemasyarakatan di indonesia berubah. Kebijakan pemerintah menekan lajunya penyebaran wabah Covid-19 ini sampai ke proses akhir pemidanaan ini. Lembaga Pemasyarakatan, Lembaga Pembinaan Khusus Anak, dan Rumah Tahanan Negara merupakan sebuah institusi tertutup yang memiliki tingkat hunian tinggi, sangat rentan terhadap penyebaran dan penularan Covid-19. Untuk melakukan upaya penyelamatan terhadap narapidana dan anak yang berada di Lembaga Pemasyarakatan, Lembaga Pembinaan Khusus Anak, dan Rumah Tahanan Negara, Pemerintah melalui Menteri Hukum dan HAM RI mengeluarkan sebuah Produ Hukum yakni Peraturan Menteri Hukum Dan Hak Asasi Manusia Republik Indonesia Nomor 10 Tahun 2020 Tentang Syarat Pemberian Asimilasi Dan Hak Integrasi Bagi Narapidana Dan Anak Dalam Rangka Pencegahan Dan Penanggulangan Penyebaran Covid-19. 
Peraturan ini mendapatkan tanggapan pro dan kontra di tengah masyarakat. Akan tetapi diluar daripada itu peraturan ini ditetapkan dalam rangka penanggulangan dan pencegahan penyebaran Covid-19 ditengah kondisi sejumlah Lapas dan Rutan yang menampung nnarapidana dan tahanan melebihi kapasitas yang ada (overcrowding). Keadaan seperti ini yang menyebabkan kebijakan kesehatan seperti Physical Distancing tidak dapat diterapkan di dalam Lapas dan rutan.

Tugas Pemasyarakatan hanya melakukan pembinaan dan pem-bimbingan dengan harapan Narapidana menjadi manusia seutuhnya, menyadari kesalahan, memperbaiki diri, dan tidak mengulangi tindak pidana sehingga dapat diterima kembali oleh lingkungan masyarakat, dapat aktif berperan dalam pembangunan dan dapat hidup secara wajar sebagai warga negara yang baik, dan bertanggungjawab.

Dengan dikeluarkannya Permenkumham Nomor 10 Tahun 2020 tentang Syarat Pemberian Asimilasi Dan Hak Integrasi Bagi Narapidana Dan Anak Dalam Rangka Pencegahan Dan Penanggulangan Penyebaran Covid-19 dan juga Keputusan Menteri Hukun dan HAM No. M.HH-19.PK.01.04.04 Tahun 2020 yang mengatur pelaksanaan tentang pengeluaran dan pembebasan narapidana dan Anak melalui asimilasi dan intergrasi, maka di titik ini program pembimbingan diharapkan dapat dijalankan oleh Narapidana yang mendapatkan program asimilasi dan reintegrasi setelah melalui prosedur-prosedur yang telah ditetapkan. Mekanisme pengawasan pun dilakukan secara intensif oleh Pembimbing Kemasyarakatan dengan menggunakan cara-cara pengawasan yang kekinian melalui online (daring).

Program pembinaan dan pembimbingan tidak akan berjalan dengan optimal tanpa dukungan dari semua pihak, termasuk pemerintah daerah dan masyarakat. Pemerintah daerah dapat turut mengawasi dari pejabat yang paling dekat dengan masyarakat yaitu RT dan mendorong agar Narapidana yang sedang menjalani program asimilasi dan klien Pemasyarakatan yang menjalani reintegrasi dapat berkontribusi dalam memajukan pembangunan daerah. Masyarakat pun diharapakan dapat memberikan kepercayaan serta dukungan moral agar meraka dapat kembali bermasyarakat.

Pada tanggal 18 Desember 2020, Menteri Hukum dan Hak Asasi Manusia Republik Indonesia menetapkan aturan terbaru yakni Peraturan Menteri Hukum dan Hak Asasi Manusia Republik Indonesia Nomor 32 Tahun 2020 tentang Syarat dan Tata Cara Pemberian Asimilasi, Pembebasan Bersyarat, Cuti Menjelang Bebas, dan Cuti Bersyarat bagi Narapidana dan Anak dalam rangka Pencegahan dan Penanggulangan Penyebaran Covid-19.

Perbedaan dari Peraturan Menteri Hukum Dan Hak Asasi Manusia Republik Indonesia Nomor 10 Tahun 2020 Tentang Syarat Pemberian Asimilasi Dan Hak Integrasi Bagi Narapidana Dan Anak Dalam Rangka Pencegahan Dan Penanggulangan Penyebaran Covid-19 dengan Peraturan Menteri Hukum dan Hak Asasi Manusia Republik Indonesia Nomor 32 Tahun 2020 tentang Syarat dan Tata Cara Pemberian Asimilasi, Pembebasan Bersyarat, Cuti Menjelang Bebas, dan Cuti Bersyarat bagi Narapidana dan Anak dalam rangka Pencegahan dan Penanggulangan Penyebaran Covid-19 dapat dilihat dari beberapa poin perubahan antara lain:

1. Perubahan Judul dengan Mengurai Integrasi Menjadi Pembebasan Bersyarat, Cuti Menjelang Bebas, dan Cuti Bersyarat 
Poin ini memberikan kejelasan kepada masyarakat dan Pejabat-Pejabat pengguna Peraturan Menteri Hukum dan HAM ini tentang pemberian hak integrasi yang meliputi Pembebasan Bersyarat dan Cuti Bersyarat karena hak integrasi lebih jelas.

2. Penambahan Substansi Pemberian Asimilasi Bagi Narapidana/Anak Warga Negara Asing

Poin ini ditujukan untuk mengakomodir tuntutan masyarakat, menghindari pelanggaran terhadap asas non diskriminatif, dan mekanisme penunjukan tempat asimilasi bagi warga negara asing. Jadi disini dapat mencerminkan persamaan hukum terhadap siapa saja yang sedang menjalani pidana di Indonesia.

3. Penambahan Klausul Pengecualian Syarat Bagi Pidana Singkat

Poin ini mengakomodir pidana dibawah 6 bulan bagi Narapidana dan dibawah 3 bulan bagi Anak.

4. Perubahan dan Penambahan Syarat Asimilasi

Pada poin ini dijelaskan syarat tambahan bagi Narapidana/Anak yang akan mendapatkan program yaitu mewajibkan adanya Penelitian Kemasyarakatan (Litmas). Pada Peraturan Menteri Hukum Dan Hak Asasi Manusia Republik Indonesia Nomor 10 Tahun 2020 memang tidak disyaratkan Litmas. Ini juga bertujuan untuk mempercepat proses Asimilasi dimaksud mengingat kondisi kedaruratan akibat Covid19 ini.

5. Penambahan Alternatif Tindak Pidana

Poin ini sebagai alternatif perumusan substansi yang mengakomodir pelaku tindak pidana pencurian, pembunuhan, dan asusila

6. Alternatif Tindak Pidana Yang Tidak Diberikan Asimilasi

Pada poin ini dijelaskan bahwa Asimilasi tidak bisa diberikan bagi Narapidana yang mengulangi tindak pidana dan tindak pidana yang sangat menarik perhatian masyarakat.

B. Kendala yang Dihadapi Balai Pemasyarakatan Klas I Padang dalam Pemberian Asimilasi Bagi Narapidana Dalam Rangka Pelaksanaan Integrasi Untuk Pencegahan dan Penanggulangan Penyebaran Covid-19

Dalam perjalanan waktu yang cukup singkat terkait pelaksanaan pemberian asimilasi dan hak integrasi bagi Narapidana ini dimasa Pandemi ini tidaklah selalu mulus berjalan. Ini sangat dirasakan oleh Pembimbing Kemasyarakatan Pada Balai Pemasyarakatan Klas I Padang. Berbagai hambatan menghiasi setiap langkah pekerjaan Pembimbing Kemasyarakatan di Bapas ini. Adapun kendala yang dihadapi Balai Pemasyarakatan Klas I Padang dalam pelaksanaan pemberian asimilasi dan hak integrasi bagi narapidana dalam rangka pencegahan dan penanggulangan penyebaran Covid-19 adalah sebagai berikut

\section{Hambatan Internal}

a. Klien

Data klien yang dikeluarkan dari Lapas/Rutan melalui program asimilasi di Bapas Kelas I Padang pada dari Bulan Mei 2020 berjumlah 1.646 orang narapidana. Jumlah klien akan mempengaruhi pengawasan yang dilakukan. Dengan sistem yang dibangun secara digital melalui Sistem Database Pemasyarakatan (SDP), jumlah klien yang cukup banyak ini bisa cepat diproses secara online. 
Akan tetapi kemampuan klien dalam memanfaatkan teknologi informasi juga sangat mempengaruhi keberhasilan pembimbingan dan pengawasan secara daring. Disisi lain faktor ekonomi mempengaruhi kemampuan klien dalam kepemilikan gadget atau handphone, minimnya pihak-pihak yang terkait yang dapat mendukung daring adalah hal-hal yang dapat menjadi faktor penghambat dalam pengawasan daring.

\section{b. SDM Pembimbing Kemasyarakatan (PK)}

Tabel 1 Data Jumlah Sumber daya Manusia (SDM) Balai Pemasyarakatan Klas I Padang

\begin{tabular}{|c|l|c|}
\hline No & \multicolumn{1}{|c|}{ Status Pegawai } & Jumlah \\
\hline 1 & Struktural & 13 \\
\hline 2 & Fungsional Umum (Staf) & 12 \\
\hline 3 & Fungsional Tertentu (PK) & 45 \\
\hline \multicolumn{2}{|c|}{ Jumlah } & $\mathbf{7 0}$ \\
\hline
\end{tabular}

Sumber Data : Balai Pemasyarakatan Kelas I Padang Tahun 2021

Pada tabel diatas dapat dilihat jumlah Pembimbing Kemasyarakatan (PK) sebanyak 45 orang. Pada tahun 2020, masing-masing PK rata-rata mendapatkan klien 30 orang untuk dibimbing melalui program asimilasi rumah. Over Kapasitas kerja terjadi disini yang membuat kewalahan Pembimbing Kemasyarakatan.

\section{c. Sistem Pelaksanaan}

Pada tahun 2020 menggunakan Permenkumham Nomor 10 Tahun 2020 tentang Syarat Pemberiaan Asimilasi Dan Hak Integrasi Bagi Narapidana dan Anak Dalam Rangka Pencegahan dan Penanggulangan Penyebaran Covid-19, pengeluaran Narapidana tidak didasarkan atas penelitian kemasyarakatan dan asesmen resiko residivis (RRI) dan Faktor Kriminogenik. Hal ini menjadikan pembimbingan dan pengawasan yang dilakukan PK minim data, kurang terjalin kedekatan dengan klien, yang berakibat pada proses pembimbingan tidak berjalan dengan baik. Selain itu pengelolaan administrasi seperti penyerahan klien dilakukan secara daring dan berkas pendukung data klien terbatas menyebabkan klien tidak teregistrasi secara akurat.

\section{Hambatan Eksternal}

Faktor kebudayaan masayarakat Sumatera Barat yang di dominasi oleh masayarakat suku minang cenderung memiliki stigma negatif terhadap narapidana dan memilih untuk memberikan hukuman sosial dengan menjauhi narapidana karena mereka berbahaya.

Peranan masyarakat dalam proses Asimilasi dibagi menjadi dua yaitu peran masyarakat saat proses pemberian izin Asimilasi dan saat pelaksanaan Asimilasi. Peran masyarakat ketika proses pemberian izin Asimilasi berkaitan erat dengan adanya peran keluarga yang bersedia memberikan surat jaminan untuk narapidana sebagai bagian dari syarat administratif. Keluarga adalah wujud dari masyarakat terkecil dan terdekat dengan narapidana. Dengan bersedia memberikan surat jaminan untuk narapidana, keluarga telah memberikan dukungan kepada narapidana untuk berbaur kepada masyarakat di sekitar LAPAS, sehingga menumbuhkan kepercayaan diri narapidana untuk bersosialisasi dengan masyarakat umum. Selain itu di dalam surat jaminan 
tersebut terdapat tanda tangan Lurah dan Camat. Hal ini menandakan bahwa masyarakat daerah asal narapidana yang diwakili oleh pejabat kelurahan juga memberikan dukungan kepada narapidana tersebut.

Peran masyarakat ketika peaksanaan Asimilasi dilihat dari tinggi rendahnya antusiasme dan partisipasi masyarakat sekitar ntuk bersosialisasi dengan narapidana selama mengikuti program Asimilasi di rumah. Asimilasi ini berjalan efektif dengan ditandai bahwa narapidana setelah bebas dari lembaga pemasyarakatan dapat diterima oleh masyarakat, yaitu narapidana tersebut kini hidup normal ditengah-tengah masyarakat.

Keadaan tersebut apabila dikaitkan dengan Teori tentang Bekerjanya Hukum dalam masyarakat menurut Robert B. Seidman, bekerjanya hukum dalam hal ini hukum untuk mencapai tujuan pemasyarakatan dipengaruhi oleh komponen-komponen yaitu lembaga pembuat peraturan, lembaga penerapan peraturan dan pemegang peranan. ${ }^{3}$ Sebaik apapun tujuan dari lembaga pembuat peraturan membuat suatu peraturan dan sebaik apapun lembaga penerapan peraturan (lembaga pemasyarakatan) menerapkan peraturan, tidak akan tercapai tujuan pemasyarakatan apabila tidak mendapat dukungan dari pemegang peranan, dalam hal ini masyarakat dan instansi terkait lainnya. Sebaik apapun perilaku narapidana itu di dalam lembaga pemasyarakatan, apabila masyarakat tidak terbuka untuk menerima maka sia-sia usaha dari lembaga pemasyarakatan melaksanakan perintah perundang-undangan.

Hal ini didukung pula dengan teori tentang sistem hukum menurut Lawrance M. Friedman bahwa tidak berfungsinya komponen masyarakat dipengaruhi oleh budaya hukum masyarakat. ${ }^{4}$ Dalam pelaksanaan hak-hak narapidana sangat penting demi terwujudnya pelaksanaan hak tersebut. Masyarakat menjadi salah satu wadah untuk mengembalikan narapidana dalam kehidupan bermasyarakat melalui proses asimilasi. Namun kadang kala tidak sesuai harapan karena masyarakat takut dan khawatir dengan kehadiran narapidana ke lingkungan masyarakat. Kekhawatiran tersebut apabila narapidana melakukan tindak pidana lagi atau membuat kekacauan ditengah masyarakat. Hal tersebut juga berdampak secara psikologis terhadap narapidana karena merasa tertekan oleh pandangan masyarakat terhadap mereka ketika mencoba untuk bermasyarakat, sehingga beberapa narapidana tidak ingin ber Asimilasi.

\section{Upaya Yang dilakukan Balai Pemasyarakatan Klas I Padang Untuk Mengatasi Kendala dalam Pemberian Asimilasi Bagi Narapidana dalam Rangka Pelaksanaan Integrasi Untuk Pencegahan dan Penanggulangan Penyebaran Covid-19}

Dari kendala yang dihadapi Balai Pemasyarakatan Klas I Padang Pelaksanaan Pemberian Asimilasi dan Hak Integrasi Bagi Narapidana dalam Rangka Pencegahan dan Penanggulangan Penyebaran Covid-19 ini ada beberapa upaya yang dapat dilakukan agar kendala tersebut tidak menjadi suatu penghambat dalam pelaksanaan Pemberian Asimilasi dan Hak Integrasi Bagi Narapidana. Adapun upaya yang dapat dilakukan adalah sebagai berikut:

${ }^{3}$ Satjipto Rahardjo, Hukum dan Masyarakat. Bandung, 1980, hlm. 28.

4 Lawrence M. Friedman, Sistem Hukum: Perspektif Ilmu Sosial, Penerjemah: M. Khosim, diterjemahkan dari buku Lawrence M. Friedman, The Legal System: A Social Science Perspective (New York: Russel Sage Fundation, 1975). Bandung, Nusa Media, 2009, hlm.. 5-6 


\section{Upaya Dalam Mengatasi Hambatan Internal}

\section{a. Klien}

Kemampuan klien dalam memanfaatkan teknologi informasi dan faktor ekonomi yang mempengaruhi kemampuan klien dalam kepemilikan gadget atau handphone, minimnya pihak-pihak terkait yang dapat menjadi faktor penghambat dalam pengawasan daring dengan solusi turunnya ke lapangan Pembimbing Kemasyarakatan secara langsung untuk mengunjungi klien. Ini dilakukan apabila putus kontak dengan Klien dan atau klien memang benar-benar tidak ada akses untuk daring.

\section{b. SDM Pembimbing Kemasyarakatan (PK)}

Untuk melakukan program Asimilasi ini secara maksimal, PK selalu bekerja sampai diluar jam kedinasan agar seluruh klien dapat terpantau dan dibimbing sesuai dengan tujuan. Dengan kata lain, pembimbing Kemasyarakatan selalu lembut untuk memenuhi semua permintaan Pembimbingan.

\section{c. Sistem Pelaksanaan}

Upaya yang dilakukan Pembimbing Kemasyarakatan adalah dengan memaksimalkan bimbingan daring dan berkoordinasi dengan aparat setempat untuk mengetahui informasi lebih mendalam terhadap klien. Aparat yang dapat dilakukan koordinasi dan kerjasama adalah mulai dari tingkat Kelurahan dan Kepolisian Sektor.

\section{Upaya Dalam Mengatasi Hambatan Eksternal}

Upaya yang dilakukan Balai Pemasyarakatan terkait problem kebudayaan masyarakat serta peran serta masyarakat dalam mendukung program ini adalah dengan melakukan sosialisasi kepada masyarakat bekerjasama dengan Penyuluh Hukum Kantor Wilayah Kementerian Hukum dan HAM. Pemahaman-pemahaman disampaikan kepada masyarakat terkait eks narapidana agar bisa diterima dan berinteraksi secara normal ditengah-tengah masyarakat. Sosialisasi yang disampaikan melalui sosialisasi langsung bertatap muka maupun tidak langsung melalui media sosial, radio, televisi dan bahan cetakan. Kegiatan penyuluhan hukum ini melibatkan aparat pemerintahan setempat seperti RT, RW dan Lurah agar akses informasi benarbenar sampai.

\section{KESIMPULAN}

Pemberian asimilasi bagi narapidana dalam rangka pelaksanaan integrasi untuk pencegahan dan penanggulangan penyebaran covid-19 dilakukan melalui sistem informasi pemasyarakatan yang merupakan sebuah website dari Direktorat Jenderal Pemasyarakatan Kementerian Hukum dan HAM RI dengan ketentuan narapidana yang 2/3 masa pidananya jatuh sampai dengan tanggal 31 Desember 2020, anak yang 1/2 masa pidananya jatuh sampai dengan tanggal 31 Desember 2020, narapidana yang tidak terkait dengan PP 99 Tahun 2012, yang tidak sedang menjalani subsidaer dan bukan warga negara asing. Asimilasi ini dilaksanakan di rumah dan surat keputusan asimilasi diterbitkan oleh KaLapas, Ka.LPKA, dan Karutan. Mekanisme pembimbingan dan pengawasan adalah Melakukan penerimaan narapidana secara daring, melakukan registrasi dan pencatatan identitas dengan menggunakan Buku Register Pembimbingan Asimilasi Narapidana (Buku Reg IX. B) dan Buku Register 
Pembimbingan Asimilasi Anak (Buku Reg IV.I), melakukan pencetakan surat keputusan integrasi serta memindahkan status registrasi narapidana ke dalam register integrasi, melaporkan pelaksanaan penerimaan narapidana kepada Kanwil dengan tembusan kepada dirjen PAS, Polres, dan Kajari setempat, menunjuk PK untuk melaksanakan pembimbingan dan pengawasan secara daring, menyampaikan laporan mengenai pelaksanaan pembimbingan dan pengawasan oleh petugas registrasi Bapas kepada Kanwil dengan tembusan Dirjen PAS, Polres dan Kajari setempat, melimpahkan pembimbingan dan pengawasan, dalam hal narapidana di luar wilayah kerja Bapas setempat dan Pengawasan oleh Bapas selama Pembinaan.

Kendala yang dihadapi Balai Pemasyarakatan Klas I Padang dalam Pemberian asimilasi bagi narapidana dalam rangka pelaksanaan integrasi untuk pencegahan dan penanggulangan penyebaran covid-19 adalah hambatan internal yang meliputi keterbatasan klien dalam penggunaan teknologi informasi, kurangnya SDM Pembimbing Kemasyarakatan serta sistem pelaksanaan daring yang terdapat kelemahan. Selain itu juga terdapat hambatan eksternal yang berasal dari lingkungan masyarakat yang kurang bisa menerima Narapidana tersebut. Upaya Yang dilakukan Balai Pemasyarakatan Klas I Padang Untuk Mengatasi Kendala dalam Pemberian asimilasi bagi narapidana dalam rangka pelaksanaan integrasi untuk pencegahan dan penanggulangan penyebaran covid-19 adalah turun langsung ke lapangan untuk mengunjungi klien, PK selalu bekerja sampai diluar jam kedinasan agar seluruh klien dapat terpantau dan dibimbing sesuai dengan tujuan, dilakukan koordinasi dan kerjasama dengan pihak Kelurahan dan Kepolisian Sektor dan melakukan sosialisasi kepada masyarakat bekerjasama dengan Penyuluh Hukum melalui sosialisasi langsung bertatap muka maupun tidak langsung melalui media sosial, radio, televisi dan bahan cetakan.

\section{DAFTAR PUSTAKA}

Lawrence M. Friedman, Sistem Hukum: Perspektif Ilmu Sosial, Penerjemah: M. Khosim, diterjemahkan dari buku Lawrence M. Friedman, The Legal System: A Social Science Perspective (New York: Russel Sage Fundation, 1975). Bandung, Nusa Media, 2009

Satjipto Rahardjo, Hukum dan Masyarakat. Bandung, 1980

Safaruddin Harefa, Kebijakan Kriminal Dalam Menanggulangi Kelebihan Kapasitas Lembaga Pemasyarakatan, Jurnal Yuridis, Volume 5, No.2, 2020

Undang-undang Dasar Negara Republik Indonesia Tahun 1945

Undang-Undang Nomor 1 Tahun 1946 tentang Peraturan Hukum Pidana

Undang-Undang Nomor 8 Tahun 1981 tentang Hukum Acara Pidana

Undang-undang Republik Indonesia Nomor 12 Tahun 1995 tentang Pemasyarakatan

Undang-undang Republik Indonesia Nomor 39 Tahun 1999 tentang Hak Asasi Manusia

Peraturan Pemerintah Nomor 32 Tahun 1999 tentang Syarat dan Tata Cara Pelaksanaan Hak Warga Binaan Pemasyarakatan 
Peraturan Pemerintah Republik Indonesia Nomor 28 Tahun 2006 Tentang Perubahan Atas Peraturan Pemerintah Nomor 32 Tahun 1999 Tentang Syarat Dan Tata Cara Pelaksanaan Hak Warga Binaan Pemasyarakatan

Peraturan Pemerintah Republik Indonesia Nomor 99 Tahun 2012 Tentang Perubahan Kedua Atas Peraturan Pemerintah Nomor 32 Tahun 1999 Tentang Syarat Dan Tata Cara Pelaksanaan Hak Warga Binaan Pemasyarakatan

Peraturan Menteri Hukum dan HAM RI No.10 Tahun 2020 Tentang Syarat Pemberian Asimilasi dan Hak Integrasi Bagi Narapidana dan Anak dalam Rangka Pencegahan dan Penanggulangan Penyebaran Covid-19

Peraturan Menteri Hukum dan Hak Asasi Manusia Republik Indonesia Nomor 32 Tahun 2020 tentang Syarat dan Tata Cara Pemberian Asimilasi, Pembebasan Bersyarat, Cuti Menjelang Bebas, dan Cuti Bersyarat bagi Narapidana dan Anak dalam rangka Pencegahan dan Penanggulangan Penyebaran Covid-19

Keputusan Menteri Kehakiman RI No. 02.PK.07.03 Tahun 1997 Tentang Organisasi dan Tata Kerja Balai Pemasyarakatan

Keputusan Menteri Hukum dan HAM RI No.19.PK.01.04 Tahun 2020 tentang Pengeluaran dan Pembebasan Narapidana Anak Melalui Asimilasi dan Integrasi dalam Rangka Pencegahan dan Penanggulangan Penyebaran Covid-19.

OKENEWS, Polemik Pembebasan Napi Ditengah Pandemi Covid-19, https://nasional.okezone.com/read/2020/04/12/337/2197945/polemik-pembebasannapi-di-tengah-pandemi-covid-19[10/11/2020] 